\title{
Waste Dump Closure and Cost Estimates at AngloGold Ashanti Iduapriem*
}

\author{
${ }^{1}$ K. O. A. Arhinful and ${ }^{2}$ G. Agyei \\ ${ }^{1}$ Quantum LC Company Limited, PO Box AT 1995, Accra, Ghana \\ ${ }^{2}$ University of Mines and Technology, P.O. Box 237, Tarkwa, Ghana
}

Arhinful, K.O.A and Agyei, G. (2017), "Waste Dump Closure and Cost Estimates at AngloGold Ashanti Iduapriem”, Ghana Mining Journal, Vol. 17, No. 2, pp. 32 - 38.

\begin{abstract}
AngloGold Ashanti Iduapriem Mine is a surface gold mine which produces waste rock in its operations. The waste rock forms waste dumps which grow over the years, and will ultimately need to be closed down when they are filled to the maximum capacity. The mine has closure plans for the waste dumps and the closure activity will incur cost. This research was carried out to study the waste dump reclamation and closure plan for the Ajopa waste dump, and estimate the associated cost. The aim of the closure is to establish a permanent stable landscape that is environmentally compatible with surrounding undisturbed land. The waste dump will be closed with a progressive rehabilitation technique. The key activities involved in the reclamation plan, which are earthworks, capping and revegetation were identified and studied into detail. The reclamation plan and cost estimates were prepared on the basis that AngloGold Ashanti Iduapriem Mine would contract with a third-party contractor to fully execute the required closure and reclamation activities. The cost was then estimated using price quotes from vendors or contractors located around the mining area. Results showed that waste dump closure and reclamation programme for Iduapriem Mine are consistent with Ghana Mining and Environmental guidelines. The total closure and reclamation cost was estimated to be US\$ 581 488.18. Since any delay in the closure and reclamation could incur additional cost, it was advised that the mine should execute the closure and reclamation plan without delay.
\end{abstract}

Keywords: Waste Dump, Reclamation, Revegetation, Estimates

\section{Introduction}

Waste is a general term for materials which currently have little or no economic value. In view of this, waste dumps are designed to manage the waste rocks generated, which are known to be associated with diverse chemical and physical impacts on miners, communities and other elements of the surrounding ecosystem.

While many other mine wastes are used for other purposes, mining companies manage their waste in order to deal with the large volumes produced and to prevent the release of contaminates into the environment. Waste management is the handling, transporting and placing of mine waste to meet stability and environmental goals by the most economical means (Zahl et al., 1992). Management and closure plans for these waste dumps have therefore been significant and are developed as part of the mine approval process, and consist of strategies to address problematic waste and longterm stabilisation of waste as part of mine closure.

Mine waste includes all materials that must be removed to gain access to the ore. It includes materials generated during the extraction, beneficiation, and processing of the mineral ores. The type, amount, and properties of mine waste produced at different mines vary depending on the resource being mined, process technology used, and geology at the mine site.
Waste rock is often stored in heaps or dumps on the mine site, but may be stored under water with tailings if it contains a lot of sulphide minerals and has a high potential for acid rock drainage formation. Waste rock dumps are generally covered with soil and re-vegetated following mine closure, although there are cases of waste rock being remined due to an increase in mineral market prices or improvements in extraction technology.

AngloGold Ashanti Iduapriem Mine is an open pit mine producing gold. The stripping ratio of the mine is about $4.4: 1$, implying that for every tonne of ore mined, 4.4 tonnes of waste material must be removed and dumped. On the average, the mine strips about 17925928 tonnes of waste per year to the waste dumps. The mine has three active waste dumps: Waste Dump 4, Waste Dump 6 and Ajopa Waste Dump, which are all of about equal capacity and can altogether take up to 80569028 tonnes of waste material. The waste dumps have been growing over the years, and will ultimately need to be closed down when they are filled to the maximum capacity. The objectives of this paper are to determine a cost effective reclamation programme for the Ajopa waste dump that conforms with the mining laws of Ghana and determine the total cost of closure. 


\section{Resources and Methods Used}

In order to fulfill the objectives, the following methods were used:

(i) Literature review on standard waste dump closure plans and activities;

(ii) Field visits and collection of data on the Ajopa Waste Dump closure and reclamation plans; and

(iii) Estimation of the cost of executing the waste dump closure plan using analytical methods.

\section{Results and Discussion}

\subsection{Closure, Rehabilitation and Cost Estimates}

Waste dump closure is executed mainly as a responsibility of the Environmental, Mining, Processing and Finance Departments. It is required by regulation that closure and rehabilitation be considered in the initial design of the waste dump. The Environmental Impact Assessment Plan (EIA), mine rehabilitation and closure plan must be submitted to the EPA before permit is granted for operations to commence. To ensure that the rehabilitation and closure plans stated by the company will be done, a Reclamation Bond which serves as security must be posted. As reclamation goes on, the commensurate amount of the bond can be reclaimed (Quaicoe, 2015).

\subsection{Reclamation Objectives and Targets}

The aim of the closure is to establish a permanent stable landscape that is aesthetically or environmentally compatible with surrounding undisturbed land. The two distinct requirements of waste dump reclamation are re-contouring the spoil piles to a satisfactory landscape and revegetation of the re-contoured lands. The rehabilitation objectives of AngloGold Ashanti Iduapriem Mine should be consistent with Ghana Mining and Environmental Regulations, Corporate Rehabilitation and Closure Standards, and must take into account stakeholder concerns towards land use and best practice rehabilitation management standard. The Ghana mining and environmental regulation identifies lands which are restorable and those which are not (Quaicoe, 2015).

The following reclamation objectives are specified for restorable land:

(i) The land must be chemically and physically stable;

(ii) The land must be left in a safe condition; and

(iii) The land should be returned to its premining capability.
In line with Corporate Management Requirement the following closure and reclamation objectives are proposed at AngloGold Iduapriem Mine (Quaicoe, 2015):

(i) Minimise pollution;

(ii) Remediate degraded areas, polluted soils and water;

(iii) Establish sustainable ecosystems;

(iv) Maximise the use of existing structures and infrastructure for future economic benefit;

(v) Provide a safe environment; and

(vi) Facilitate sustainable livelihoods of affected communities, in accordance with the Social Investment and Local Economic Development Management Standard and the Stakeholder Engagement Management Standard, as applicable.

\subsection{Waste Dump Closure and Reclamation Principles at AngloGold Ashanti Iduapriem}

The basic principles of reclamation, which will be followed by AngloGold Ashanti Iduapriem Mine as specified in the Environmental Impact Statement (EIS) are (Anon., 2016a):

(i) Progressively rehabilitate the project area where possible;

(ii) Reshape the land disturbed by operations to the greatest extent possible so that it is stable, adequately drained to minimise erosion, suitable for the desired long term land use, and its surface is adequate for revegetation in accordance with Ghana Environmental Protection Agency regulations;

(iii) Characterise and store the topsoil for use in reclamation;

(iv) If topsoil is unsuitable or absent, identify and test alternative substrates such as overburden or oxidised waste material;

(v) Use, to the greatest extent possible, at least $40 \%$ of local plant species or species that have proven to be adapted to the local environmental conditions for revegetation;

(vi) Avoid, to the greatest extent possible, introduction of noxious weeds into the project area;

(vii) Remove all facilities and equipment from the site which are not required by the proposed closure plan (except those retained by government as per conditions in the Mining Lease);

(viii) Remove or control residual hazardous materials;

(ix) Identify potentially toxic overburden or exposed strata and manage them so as to prevent any damage to the environment; and 
(x) Monitor and manage rehabilitated areas until the vegetation is self-sustaining and all other reclamation objectives are met.

\subsection{The Ajopa Waste Dump Closure Plan Criteria at AngloGold Ashanti}

From the Reclamation Security Agreement between the mine and the Environmental Protection Agency (EPA), the standards for the closure of the mine waste dump are as follows (Anon., 2016b):

(i) Create stable slopes and surfaces free from rock and soil movement;

(ii) The slope of the base lift of the dump to be battered between $20^{\circ}-30^{\circ}$ with a lift height of less than or equal to $20 \mathrm{~m}$ provided in the design and or implemented during construction;

(iii) Water run-offs must be managed effectively and efficiently;

(iv) Keep gentle rolling landforms of similar aesthetics to existing area;

(v) Waste rock dump must be constructed to ensure chemical stability;

(vi) The combined topsoil and subsoil cover on waste dump must be at least of $0.5 \mathrm{~m}$ thickness; and

(vii) Soils must be stable and free from erosion through the provision of vegetative cover.

\subsection{Closure and Rehabilitation Process}

\subsubsection{Progressive Rehabilitation}

The Ajopa waste dump as illustrated in Fig.1, will be closed with a progressive rehabilitation technique. The waste dump will be revegetated as soon as possible when work or dumping in a specific area of the dump site is over and the area can be restored even as work or dumping continues at other parts of the dump site.

The primary objective of progressive reclamation is to reduce loads to the tailings impoundment and subsequently to the water treatment plant. In addition, progressive reclamation will allow more efficient utilisation of the existing equipment, and will allow less stockpiling of cover materials from the mining operations (Anon., 2007).

It is anticipated that participation in progressive rehabilitation will reduce the period of land disturbance caused by mining and will also reduce the financial risk to governments and land owners should the miners fail to properly rehabilitate the land. The corresponding advantage for the miners is the greater certainty in respect of rehabilitation expenditure and a reduction in extra environmental liabilities for delays. It also provides an opportunity for testing rehabilitation practices, and for the gradual development and improvement of rehabilitation methods (Anon., 2006).

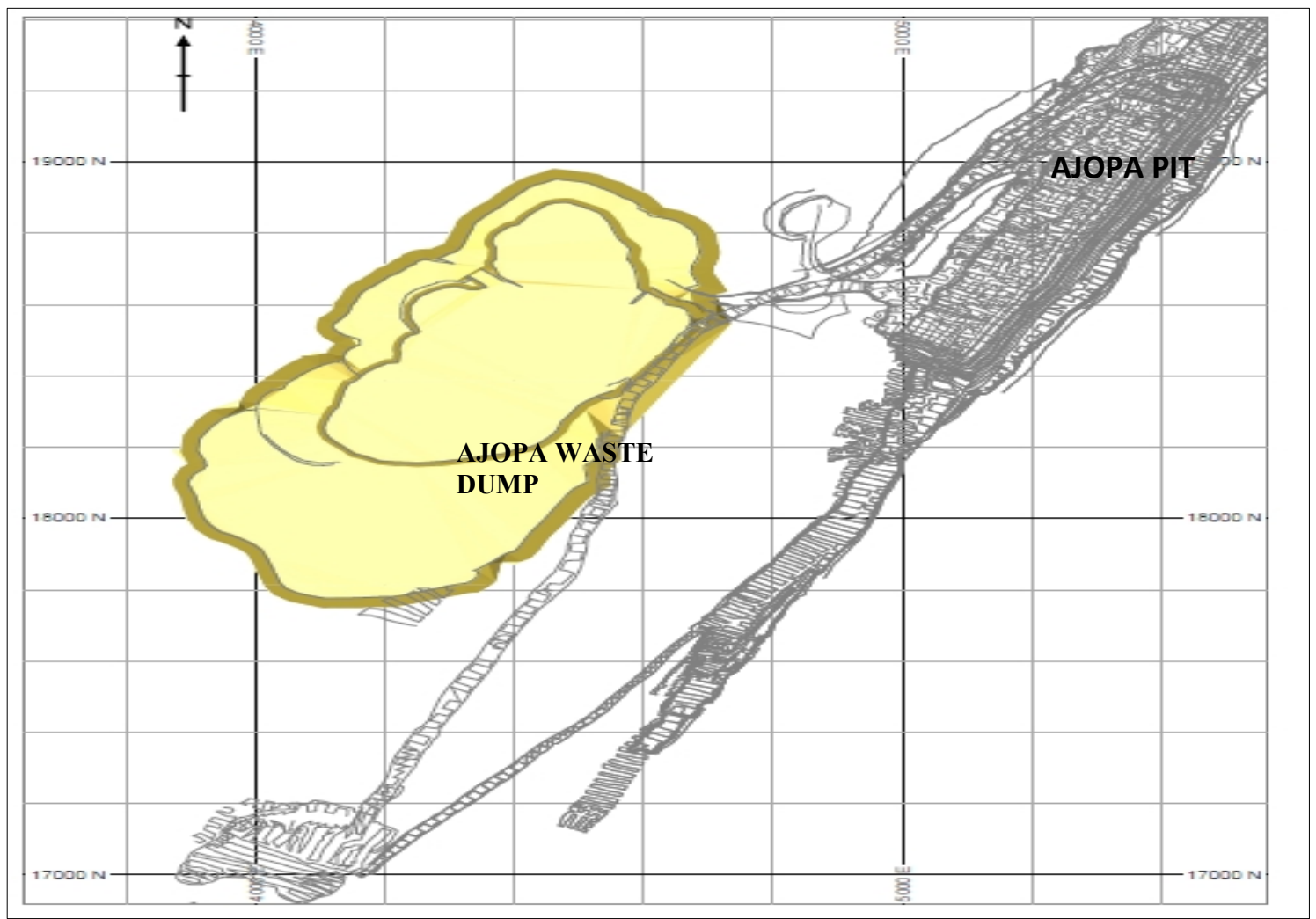

Fig.1 Overview of the Ajopa Waste Dump 


\subsubsection{Earthworks}

As per the scope of work of AngloGold Ashanti Iduapriem Mine, the key activities involved during the earthworks are battering, cutting and filling of the disturbed land areas. These activities are followed by reshaping and contouring to flatten and prepare the slope for closure and rehabilitation to conform to the surrounding landscape. The completed work should conform to the design specification and business principles of the mine (Anon., 2016a).

The designed wall should have the following specifications:

(i) Batter Angle: the batter angle of material before rehabilitation is based on the angle of repose of material, which is $38^{\circ}$. The batter angle after rehabilitation should be $25^{\circ}$ for the bottom lift.

(ii) Berm width: the berm width before rehabilitation is $10.0 \mathrm{~m}$, as per waste dump design. The berm width should be $6.0 \mathrm{~m}$ after rehabilitating the bottom lift.

(iii) Cut and Fill Volume: for rehabilitation, the expected cut volume is the same as the fill volume. The expected cut volume is approximately $78726 \mathrm{~m}^{3}$. Total horizontal distance is approximately $366 \mathrm{~m}$. Total surface area to be rehabilitated is approximately $15458 \mathrm{~m}^{2}$.

The equipment used for reshaping and contouring at AngloGold Ashanti Iduapriem Mine include excavators, bulldozers, trucks and graders. Resloping operations involve the use of dozers fitted with U-blades which are used primarily to restructure dump slopes from their $38^{\circ}$ angle to a maximum of $25^{\circ}$.

\subsubsection{Waste Rock Dump Design and Construction}

Per the Environmental Impact Statement of the Ajopa Waste Dump, the vertical dumping height for the waste rock material is $30 \mathrm{~m}$. The choice of the height is based on economics and safety. The material characteristics and dumping strategy allow for a maximum dump height of $10 \mathrm{~m}$; beyond this height, the material becomes susceptible to ground cracks and failures at the tipping ends. Dumping below $10 \mathrm{~m}$ height lift is unproductive and uneconomical since the dumping face will advance quickly, increasing the haulage distance without dumping adequate material at a single lift. The estimated total height of the waste dump will be about $30 \mathrm{~m}$ from the floor. Berm width of $15 \mathrm{~m}$ is allowed to break the continuity of otherwise long slope which may give way easily to ground failures especially during rainy season. It is integrated in the design of dump to make dozing or landscaping during rehabilitation quite an easy task (Anon., 2016a).

\subsubsection{Capping}

Capping involves spreading the disturbed surfaces with topsoil with the aim of improving conditions for stabilisation and plant growth. Information obtained through the waste characterisation during the planning phase is used to identify suitable material.

Wherever practical, the final slopes of the waste rock dumps are armoured with blocky oxidised waste rock. Where this material is unavailable, unmineralised "fresh" waste rock is to be used. Specifically, all completed surfaces of the waste dump will be stable and able to resist long term erosion. For this reason, high clay, sand or kaolin content materials are not suitable for final slopes. Mine sites are often remote and possible cover materials are frequently limited to available substrate at the mine site, which include topsoil or oxidised waste rock with fertiliser addition for the growth medium, compacted (self-healing) silty, sandy clay, compacted clayey oxidised waste rock, compacted inert fine-grained tailings or compacted or slurried tailings/waste rock mixtures for the seal, fresh waste rock with minimal fines, or quarried rock with minimal fines for the capillary break. With the use of topsoil identified as the necessary spread material, it is not to be applied over readily erodable materials such as those with high sand, clay or kaolin content. The topsoil salvaged from the advancing waste dump is immediately spread on the prepared (re-shaped) final waste dump surfaces (Davis, 2004).

\subsubsection{Revegetation}

Revegetation tasks generally consist of seedbed preparation, seeding, planting, and fertilisation. Information regarding the revegetation tasks should be determined based upon the approved reclamation plan where details regarding the depth of topsoil replacement, seed type and application rates, and fertiliser application rates can be found.

The Ajopa waste dump will be revegetated with a 3 x $3 \mathrm{~m}$ planting pattern. Grassing will be done first to control erosion, and then the tree planting exercise will follow for stability and aesthetic purposes.

Vegetative cover is one of the most important factors governing the sustainability of reclaimed disturbed areas. The vegetative canopy and surface litter plays an important role in absorbing the impact of raindrops. Even more important is the density of the fine root mass at the soil surface, which holds the soil together and minimises soil erosion. Some vegetative cover may change with 
time because of several factors such as drought. Establishing fast growing nitrogen-fixing species will increase the organic matter and nitrogen content of the various substrates, as well as controlling soil erosion, providing fuel wood, and for some species, edible fruit and medicinal products. Trials will be conducted with Bracharia, Gliricidia sepium, Acacia auriculiformis, A. angustisema, Leuceana leucocephala, L. diversifolia and Sesbania sesbans among others. The present vegetative cover in the study area portrays a disturbed community. The tree diversity is low. An ocular inspection of the flora on the hill where serious "galamsey" (i.e. small-scale illegal mining) activities take place, revealed that populations of members of the Cecropiaceae (Musanga cecropiodes and Cecropia peltata) were dominant, creating an apparent even-aged situation, and giving the impression that they may have been deliberately cultivated as a revegetation venture at some time in the recent past. Agriculture, logging, charcoal-making and mining activities may have led to the destruction and replacement of the vegetation cover by fragments of secondary forest (Anon., 2016a).

\section{Flora}

It was recognised that three storeys of trees existed in the high forest and was noted that grasses were almost absent except for Leptaspis cochleata, Streptogyne gerontogea in addition to Centotheca sp., Cyrtococcum sp., Olyra latifolia, Oplismmenus sp. and Panicum sp. Others were Bambusa vulgaris (introduced species) and Coix lachrymal-jobi. Further identification proved that the ferns Gleichenia linearis, Lygodium microphyllum and L. smithianum and one species each of Lycopodiaceae (Lycopodium cernuum) and the Selaginellaceae (Selaginella mysorus) were in the ground flora. The vegetation of Iduapriem forms part of the Ghanaian high forest. This type of forest is the most extensive closed-canopy forest type in Ghana and the tallest of any forest type; the trees tend to be 50 - $60 \mathrm{~m}$ high with several canopy layers. The common timber species in the forest includes Celtis mildbraedii, Entandrophragma utile, Guibourtia ehie, Khaya anthotheca, Khaya ivorensis, Nesogordonia papaverifera, Pericopsis elata, Terminalia ivorensis, and Triplochiton scleroxylon. However, during the last 50 years human activities such as logging, gold mining and agriculture have reduced $90 \%$ of Ghana's primary rainforest (Anon., 2016b).

\section{Fauna}

Forests ensure the survival and well-being of animals that inhabit them and those who have to use them temporarily. It has been noted that most activities of animals take place in the canopy, some 30-50 $\mathrm{m}$ above the forest floor, where photo- synthetic activity is highest. However, the current rate of forest conversion to other land use types requires that the populations of the animal species be monitored regularly in order to plan for and implement interventions that may forestall the loss of species. In the light of this, a survey was carried out at Ajopa community to make an inventory of the various animal species (mammals, birds, reptiles, and amphibians). Of the mammals, Rodentia had six (6) species, recording the highest number, followed by Carnivora and Cetartiodactyla with five (5) species each. The family Borvidae recorded four (4) species followed by the Herpestidae and Sciuridae having three (3) species each. In the case of aves, the Passeriformes occurred to be the most dominant with three (3) species. All the six (6) families contained one (1) species each except the Bucerotidae with two (2) species. The orders of the reptiles were dominated by the Squamata with three (3) species. Among the six (6) families, Boidae and Veranidae contained two (2) species each. All the species of amphibians identified belonged to different genera, families, and orders with different conservation concerns. Most of the species were not endangered but if nothing is done to conserve them, the rate of destruction of their habitat will cause them to be endangered (Anon., 2016a).

\subsubsection{Cost Estimate}

It is required that a progress report be submitted every two years to the Environmental Protection Agency (EPA) to update the reclamation and closure plan as stated in the reclamation security agreement between the mine and the EPA. The completion progress report should describe the reclamation activities that were undertaken for the reclamation domains and the value of the closure and reclamation works completed. The value of the completed closure and reclamation works form the basis of reviewing the reclamation bond, termed as the adjusted cost estimates (Quaicoe, 2015). The estimated cost of closure is found using the closure and reclamation activities and their corresponding estimated rates.

The Reclamation Plan and Cost Estimate have been prepared on the basis that AngloGold Ashanti Iduapriem Mine would contract with a third-party contractor to fully execute the required closure and reclamation activities. The plan incorporates price quotes from vendors located around the mining area as shown in Table 1 and is representative of what would be required to mobilise everything to the site for full execution of the plan requirements.

The cost of the earthwork activities is estimated using equipment which are transportable by a transporter and capable of providing the required productivity under the imposed 2-month timeline. Based on these requirements, the major equipment 
needed are $25 \mathrm{~m}^{3}$ tipper trucks, an excavator, CAT320B loader, and a bulldozer CAT 7.

Table 1 Hourly Rate

\begin{tabular}{|c|c|c|c|}
\hline Company & Equipment & $\begin{array}{c}\text { Rate/hr } \\
(\$)\end{array}$ & Location \\
\hline \multirow[t]{4}{*}{ AT S } & Bulldozer Cat 7 & 145.00 & \multirow{4}{*}{ Bogoso } \\
\hline & Excavator CaT 320B & 150.00 & \\
\hline & $\begin{array}{l}\text { Tipper Truck } \\
\left(25 \mathrm{~m}^{3}\right)\end{array}$ & 80.00 & \\
\hline & Low Bed Transporter & $1700 /$ day & \\
\hline \multirow[t]{4}{*}{ L.P.H. } & Bulldozer Cat 7 & 140 & \multirow{4}{*}{ Bogoso } \\
\hline & Excavator Cat 320B & 132 & \\
\hline & Tipper Truck $\left(25 \mathrm{~m}^{3}\right)$ & 75 & \\
\hline & Low Bed Transporter & 63 & \\
\hline \multirow{5}{*}{$\begin{array}{l}\text { Roroda } \\
\text { Ltd }\end{array}$} & Bulldozer Cat 6 & 120 & \multirow{5}{*}{ Nsuta } \\
\hline & Bulldozer Cat 7 & 130 & \\
\hline & Excavator Cat 320B & 130 & \\
\hline & Tipper Truck $\left(25 \mathrm{~m}^{3}\right)$ & 70 & \\
\hline & Low Bed Transporter & 63 & \\
\hline Castro Ltd & $\begin{array}{l}\text { Bulldozer Cat } 7 \\
\text { Excavator Cat } 320 \mathrm{~B} \\
\text { Tipper Truck }\left(25 \mathrm{~m}^{3}\right)\end{array}$ & $\begin{array}{r}140 \\
150 \\
90\end{array}$ & Tarkwa \\
\hline
\end{tabular}

Using the maximum of the vendor quotes obtained for equipment rental/lease rates (see Table 1), the estimated cost for the bulldozer CAT 7 is $\$ 145.00$ per hour. The dozer will work within a time frame of 2 months (60 days). This is equal to 1440 hours. Therefore, the total estimated cost to be paid for one dozer is: 1440 x $145.00=\underline{\text { US\$ } 208800}$.

Total volume of material to be moved is $78726 \mathrm{~m}^{3}$ Truck capacity is $25 \mathrm{~m}^{3}$

Cycle time is 20 minutes

Material moved per hour $=25 \times 3=75 \mathrm{~m}^{3}$

Time to $78726 \mathrm{~m}^{3}$ of material is:

$78726 \mathrm{~m}^{3} / 75 \mathrm{~m}^{3} / \mathrm{hr}=1049.68 \mathrm{hrs}$

Cost per truck is US\$ $90.00 / \mathrm{hr}$; the estimated cost of 1 truck is: $90 \times 1049.68=\underline{\text { US\$ } 94471.2}$

From the vendor quotes, the estimated cost for 1 excavator CAT $320 \mathrm{~B}=$ US\$ $150.00 /$ hour and as such the cost for the 2 months is given as:

$150 \times 1440=\underline{\text { US\$ } 216000}$.

The estimated cost for the excavator is therefore US\$ 216000 .

The transporter machine will transport the other needed equipment to and from the site at a cost of US\$ 700 per day, for the first day and after the work has been completed. The estimated cost is therefore: $700 \times 2=\underline{\text { US\$ } 1400}$.

The total estimated cost for the use of these equipment is US\$ $208800+94471.2+216000+1$ $400=$ US\$ 520671.2.

The capping and revegetation activity will also be given out to a third-party contractor. The cost of revegetation was estimated based on the surface area of the part of the Ajopa waste dump under reclamation. The area is approximately $15458 \mathrm{~m}^{2}$. From the vendor quotes obtained for the activities involved in the revegetation and their respective costs, the estimated cost for capping and revegetation is shown in Table 2 . The total cost of caping and revegetation is US \$ 60816.98 .

The total cost of the Ajopa Waste Dump closure and reclamation is therefore US\$ $520671.2+60$ $816.98=\underline{\text { US \$ } 581488.18}$

Table 2 Cost Estimation for the Capping and Revegetation Process

\begin{tabular}{|c|c|c|c|}
\hline Description & Unit & Rate (\$) & Amount (\$) \\
\hline $\begin{array}{l}\text { Labour cost of } \\
\text { Grassing \& } \\
\text { Planting of trees }\end{array}$ & $\mathrm{m}^{2}$ & 0.31 & 4791.98 \\
\hline $\begin{array}{l}\text { Harvesting \& } \\
\text { Transporting of } \\
\text { Bracharia and } \\
\text { gliricidia sepium } \\
\text { to site }\end{array}$ & Lot & 950 & 950.00 \\
\hline $\begin{array}{l}\text { Harvesting \& } \\
\text { Transporting of } \\
\text { Utility Trees and } \\
\text { palm tree to site }\end{array}$ & Lot & 250 & 250.00 \\
\hline $\begin{array}{l}\text { Supply of black } \\
\text { soil for planting } \\
\text { grass and tree } \\
\text { seedlings }\end{array}$ & Lot & 375 & 375.00 \\
\hline $\begin{array}{l}\text { Transportation of } \\
\text { potted seedlings } \\
\text { from the nursery }\end{array}$ & Lot & 250 & 250.00 \\
\hline $\begin{array}{l}\text { Preliminaries \& } \\
\text { Generals }\end{array}$ & Lot & 200 & 200.00 \\
\hline $\begin{array}{l}\text { Care and } \\
\text { maintenance of } \\
\text { planted trees and } \\
\text { grass for } 1 \text { year. }\end{array}$ & Monthly & 4500 & 54000.00 \\
\hline Total Cost & & & 60816.98 \\
\hline
\end{tabular}

\subsubsection{Monitoring and Maintenance}

Monitoring provides feedback mechanism regarding the success and maintenance of mitigation measures, requirement for additional and/or corrective mitigation measures as well as appraisal of the overall EIA processes (Buaba, 2015). To achieve this, AngloGold Ashanti Iduapriem Mine will use growth monitoring, as well as landscape functional analysis and soil analysis as monitoring procedures.

\section{Conclusions and Recommendations}

\subsection{Conclusion}

The following are conclusions made from the study:

(i) A cost effective reclamation programme for each waste dump in conformity with the mining laws of Ghana has been determined. 
(ii) The total estimated cost for carrying out earthworks in the closure and reclamation process is US\$ 520671.2.

(iii) The total estimated cost for carrying out capping and revegetation activities in the closure and reclamation process is US\$ 60 816.98.

(iv) The total closure and reclamation cost is therefore US\$ 581488.18 .

\subsection{Recommendations}

The following are recommendations made from the study:

(i) The mine should continue to undertake the progressive reclamation technique due to its numerous benefits for the mine and the host communities.

(ii) The Ajopa Waste Dump closure and reclamation should be done as early as possible to avoid any additional cost resulting from delay.

\section{Acknowledgements}

Our heartfelt appreciation to the management and staff of AngloGold Ashanti Iduapriem Mine for the opportunity granted to undertake this project work at the mine.

\section{References}

Anon. (2006), "Mine Rehabilitation" Leading Practice Sustainable Development Program For The Mining Industry, Department of Industry Tourism and Resources.http://www.ag.gov .au/cca. Accessed 28/12/15.

Anon. (2007), Plan of Operations for Waste Rock Management, Red Dog Mine Closure and Reclamation Plan, SRK Consulting (Canada) Inc. Vancouver, B.C. V6E 3X2, 154 pp.

Anon. (2016a), Closure and Reclamation, The Environmental Impact Statement, AngloGold Ashanti Iduapriem Mine. 166 pp.

Anon. (2016b), Reclamation Criteria, The Reclamation Security Agreement, AngloGold Ashanti Iduapriem Mine. pp. 13.

Buaba, J. A. (2015), "Waste Dump Reclamation Practices" Unpublished BSc Project Report, University of Mines and Technology, Tarkwa, pp. $10-22$.

Davis, D. (2004), “Capping”, Waste Rock Dumps Guideline, WMC Resources Ltd. pp. 9.http://www.ea.gov.au/industry/sustainable/mi ning/booklets/index.html

Quaicoe, J. (2015), "Mine Closure and Liability Estimates At AngloGold Ashanti Iduapriem Mine" Unpublished BSc Project Report, University of Mines and Technology, Tarkwa, $40 \mathrm{pp}$.
Zahl, E.G., Biggs, F., Boldt, C.M.K., Connolly, R.E., Gertsch, L., and Lambeth, R. H. (1992), Waste Disposal and Contaminant Control, in Hartman, H.L., ed., SME Mining Engineering Handbook: Littleton, CO, Society for Mining, Metallurgy and Exploration Inc., p. 1170 1180.

\section{Authors}

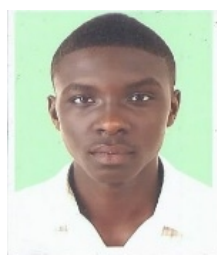

Arhinful, Kofi Owusu Achaw is a graduate Mining Engineer (First Class Honours) from the University of Mines and Technology, Tarkwa, Ghana. He is a student member of the Ghana Institute of Engineers (GhIE) and a graduate member of the Australasian Institute of Mining and Metallurgy (AusIMM). He is working as a Mining Engineer at Quantum LC Company Limited, which provides contract mining services.

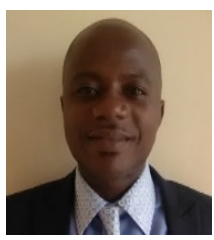

George Agyei is a Senior Lecturer in the Department of Mining Engineering, University of Mines and Technology, Tarkwa. He holds a BEng in Mining Engineering from Moa Higher Institute of Mining and Metallurgy, Cuba, an MBA in General Management from Educatis University, Altdorf, Switzerland and a $\mathrm{PhD}$ in Minerals Beneficiation from Havana, Cuba. His main research interests are Process Mineralogy, Minerals Beneficiation and Sustainable Development. 